\title{
Intra-Arterial Blood Pressure Measurement: Sources of Error and Solutions
}

Suresh Devasahayam ${ }^{1 *, \# a}$, C. Surekha ${ }^{2, \# b}$, Bowya Baskaran ${ }^{2, \# c}$, Naveen Gangadharan ${ }^{1, \# d}$, Farhan Adam Mukadam $^{2}$, \#e and Sathya Subramani ${ }^{2, \# f}$

* Corresponding author

${ }^{1}$ Department of Bioengineering, Christian Medical College Vellore, 632002, Tamilnadu, India

${ }^{2}$ Department of Physiology, Christian Medical College Vellore, 632002, Tamilnadu, India.

\#a Professor and Head, Department of Bioengineering, Christian Medical College Vellore, 632002, Tamilnadu, India

\#b Bachelor of Computer Science and Engineering, Junior Research Fellow, Department of Physiology, Christian Medical College Vellore, 632002, Tamilnadu, India.

${ }^{\# c}$ Bachelor of Electrical and Electronics Engineering, Junior Research Fellow (current): Department of Physiology, Christian Medical College Vellore, 632002, Tamilnadu, India.

\#d MS Bioengineering, Ph.D Fellow (current): Department of Engineering Design, Indian Institute of Technology Madras, Chennai, Tamilnadu, India

\#e MD Physiology, Ph.D Fellow (current): Biosystems Science and Engineering, Indian Institute of sciences, Bengaluru, Karnataka, India

\#f Professor, Department of Physiology, Christian Medical College Vellore, 632002, Tamilnadu, India

\section{*Corresponding Author: Suresh Devasahayam}

Professor, Department of Bioengineering, Christian Medical College Vellore, 632002, Tamilnadu, India.

surdev@cmcvellore.ac.in

Total word count: 6447

Subject codes: Blood Pressure, Physiology 
medRxiv preprint doi: https://doi.org/10.1101/2020.08.29.20184275; this version posted October 25, 2020. The copyright holder for this preprint (which was not certified by peer review) is the author/funder, who has granted medRxiv a license to display the preprint in perpetuity.

All rights reserved. No reuse allowed without permission.

\section{ABSTRACT}

Rationale: Intra-arterial blood pressure measurement is the cornerstone of hemodynamic monitoring in Intensive Care Units (ICU). Accuracy of the measurement is dependent on the dynamic response of the measuring system, defined by its natural frequency $\left(f_{\text {natural }}\right)$ and damping coefficient $\left(Z_{\text {damping }}\right)$ which are estimated with a Fast-flush test. Locating the experimentally measured $f_{\text {natural }}$ and $Z_{\text {damping }}$ on the plot in the original paper by Gardner (1981) which defined the acceptable limits for these 2 parameters, has long been the only way to determine the accuracy of the pressure measurement.

In this paper, we extend the current understanding of the effect of poor dynamic response of the measurement system, enhance the usefulness of Gardner's plots by providing a numerical value for the error in pressure measurement (for a given set of conditions) and depict the gradation of error value as heat maps, and also demonstrate the usefulness of a tunable filter for error correction.

Objectives: (i) Estimation of the amplitude of error in pressure measurement through simulations based on real-world data, and development of heat-maps for easy use by physicians to assess if the recording conditions are optimal (ii) A new method to correct the error.

Methods and Results: Simulated blood pressure waveforms of various heart rates and pressure levels were passed through simulated measurement systems with varying $f_{\text {natural }}$ and $Z_{\text {damping. The numerical }}$ errors in systolic and diastolic pressures and mean error in the measured pressure were used to generate heat maps denoting the errors for the various recording conditions, in the same plot as that by Gardner (1981). Performance of a tunable filter to correct the error is demonstrated.

Conclusions: In many clinical settings the measurement of intra-arterial pressure is prone to significant error. The proposed tunable filter is shown to improve the accuracy of intra-arterial pressure recording.

Key Words: $\boldsymbol{\square}$ blood pressure measurement/monitoring $\boldsymbol{\square}$ physiology $\boldsymbol{\square}$ catheter $\boldsymbol{\square}$ natural frequency -damping-coefficient Gardner's plot 
medRxiv preprint doi: https://doi.org/10.1101/2020.08.29.20184275; this version posted October 25, 2020. The copyright holder for this preprint (which was not certified by peer review) is the author/funder, who has granted medRxiv a license to display the preprint in perpetuity.

All rights reserved. No reuse allowed without permission.

\section{Introduction}

Direct measurement of arterial blood pressure using an intra-arterial cannula is a routine procedure in intensive care ${ }^{8,10}$. While a miniature pressure transducer inserted into the artery may provide the best means of measuring the pressure directly, for reasons of sterilization, size and cost the artery is accessed by a fluid-filled catheter and the transducer is connected at the outside end of the catheter. Care must be taken in ensuring that the fluid-filled catheter does not adversely alter the measurement of pressure. The measurement depends on the idea that the pressure at the catheter tip is faithfully reproduced at the transducer with little or no changes introduced by the fluid-filled length of the tube connecting the catheter and transducer. Therefore, the incompressible nature of the fluid and the inelastic nature of the catheter and connecting tube are important assumptions underlying the measurement.

A paper of fundamental importance to such measurement is that by Gardner $^{3}$, in which the requirements of such intra-arterial blood pressure measurement systems is described. The paper shows that poor dynamic response of the measurement system can seriously distort the pressure measurement and yield significantly incorrect readings.

Since the publication of that paper there is an enhanced awareness about characterization of the dynamic properties of the catheter pressure measuring system. The dynamic characterization is performed by a "Fast-flush test" wherein the quick, elastic, release of a plunger in the fluid system produces a step change in pressure. Pulling the plunger raises the pressure at the transducer to about $300 \mathrm{mmHg}$ by opening a connection to the counter-pressure saline bag, and releasing the plunger restores the pressure at the transducer to the arterial pressure. This produces a step change in pressure and a corresponding step response of the pressure measurement system. The response of the catheter system to this step change is that of a second order system. The inertance of the liquid, the resistance of the catheter system and the damping by the elastic components form a second order system. If the step-response shows a poor 
medRxiv preprint doi: https://doi.org/10.1101/2020.08.29.20184275; this version posted October 25, 2020. The copyright holder for this preprint (which was not certified by peer review) is the author/funder, who has granted medRxiv a license to display the preprint in perpetuity.

All rights reserved. No reuse allowed without permission.

frequency response or the damping is improper (too high or too low), the catheter system ought to be adjusted to improve the frequency response (i.e., improve the natural frequency, $f_{\text {natural }}$ and damping

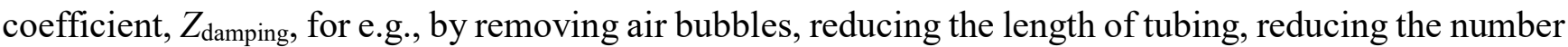
of three-way taps used in the tubing). In current clinical practice the Fast-flush test is not recorded, and no quantitative characterization is performed; there is only qualitative characterization by visual inspection. The absence of quantitative characterization of the catheter system's dynamic response can result in poor adjustment of the system and subsequently incorrect pressure measurement ${ }^{4}$.

In this paper we extend the current understanding of the effect of poor measurement conditions on intraarterial blood pressure measurement. There are two ways of studying the effect of poor system response on intra-arterial blood pressure measurement, (i) Method A: physical experimentation in which accurate recordings of arterial pressure are made, say with measuring systems with a very high natural frequency, so as to represent a wide array of true pressure wave-forms, and this data which is supposedly perfect is passed through systems simulating (either physically or virtually) various practical conditions of measurement systems, (ii) Method B: synthesize pressure waveforms based on one (or a few) carefully measured almost perfect waveform, and then virtually modify this waveform to simulate different conditions of heart rate and blood pressure levels and pass them through various simulations of measuring systems with different characteristics. Given the near impossibility of obtaining "perfectly" measured pressure waveforms as per the first method under different conditions of heart rate and blood pressure, we chose the second method in the present study.

Beginning with data from the intensive care unit (ICU) at a tertiary care center, we have simulated the catheter-based pressure measurement to determine the acceptable range of $f_{\text {natural }}$ and $Z_{\text {damping, for pressure }}$ recordings with minimal error. We identified sources of error in the measurement system and we propose some solutions. 
medRxiv preprint doi: https://doi.org/10.1101/2020.08.29.20184275; this version posted October 25, 2020. The copyright holder for this preprint (which was not certified by peer review) is the author/funder, who has granted medRxiv a license to display the preprint in perpetuity.

All rights reserved. No reuse allowed without permission.

\section{Methods}

The primary tool we have used in this study for determining the error introduced into arterial pressure measurement is a numerical simulation program to simulate the experimental condition. The program has been written in $\mathrm{C} / \mathrm{C}++$ and runs in Windows and Linux. Synthesized "true arterial pressure" wave forms were passed through a simulated measurement system of varying $f_{\text {natural }}$ and $Z_{\text {damping, }}$, and the graphical output of the simulation, i.e., "measured pressure" waveforms and Fourier spectra were generated. Errors in measured pressure were calculated as the difference between input (true pressure) and output (measured pressure) waveforms. Errors in measured systolic and diastolic pressures and mean error (of the whole pressure wave) for a given "true arterial pressure" waveform were estimated for varying combinations of $f_{\text {natural }}$ and $Z_{\text {damping }}$ by running the simulations under those conditions. The numerical errors in measured pressure for each combination of $f_{\text {natural }}$ and $Z_{\text {damping }}$ (for a given input pressure wave form) are represented as varying colors in "heat maps" in the same plot as that of Gardner, using Scilab. Details of the methods used are given below.

\section{Generation of "true arterial Pressure" Waveforms as inputs for the simulated pressure- measurement system:}

The hypothetical arterial waveform was generated based on published data that is now standard textbook material ${ }^{5,6}$. The pressure data was digitized at 1000 samples per second with the maximum and minimum scaled for simulation of different systole and diastole values. For different heart rates the waveform was time-scaled by a constant factor to obtain heart rates of 40 beats per minute (bpm) to $220 \mathrm{bpm}$. For different systolic and diastolic pressures, the waveform was amplitude scaled and shifted. This synthesized waveform termed the "true pressure wave" was passed through a virtual fluid-filled catheter measurement system. The different true pressure waveforms are time scaled and amplitude scaled and shifted versions of each other, as the heart pump is assumed to be linear in its change of rate and pressure 
medRxiv preprint doi: https://doi.org/10.1101/2020.08.29.20184275; this version posted October 25, 2020. The copyright holder for this preprint (which was not certified by peer review) is the author/funder, who has granted medRxiv a license to display the preprint in perpetuity.

All rights reserved. No reuse allowed without permission.

(see Appendix for calculation of pressure waveforms ${ }^{2}$ ). In our simulation, the change in heart rate produces a corresponding change in the frequency spectrum - higher heart rates result in a wider frequency spectrum. The amplitude scaling of the pressure waveform produces a corresponding change in the rate of pressure change and therefore a corresponding change in the frequency spectrum. Therefore, both heart rate change and pressure pulse amplitude changes lead to a change in the frequency content in the spectrum. Combining these two phenomena, a simple measure of the change in the frequency spectrum is the rise-rate of pressure during systole. We define the systolic rise-rate as the slope of the pressure waveform in the interval from the diastolic trough to the systolic peak.

The pressure waveforms for 2 different conditions were generated for input into the measurement system, (i) low heart rate of $60 \mathrm{bpm}$ and blood pressure of 120/76 $\mathrm{mmHg}$ which corresponds to a systolic riserate of $300 \mathrm{mmHg} / \mathrm{s}$, and (ii) high heart rate and blood pressure of $120 \mathrm{bpm}$ and 180/90 $\mathrm{mmHg}$ which corresponds to a systolic rise-rate of $1200 \mathrm{mmHg} / \mathrm{s}$. Figure 1 shows these two waveforms that have been used in the simulations in this study.

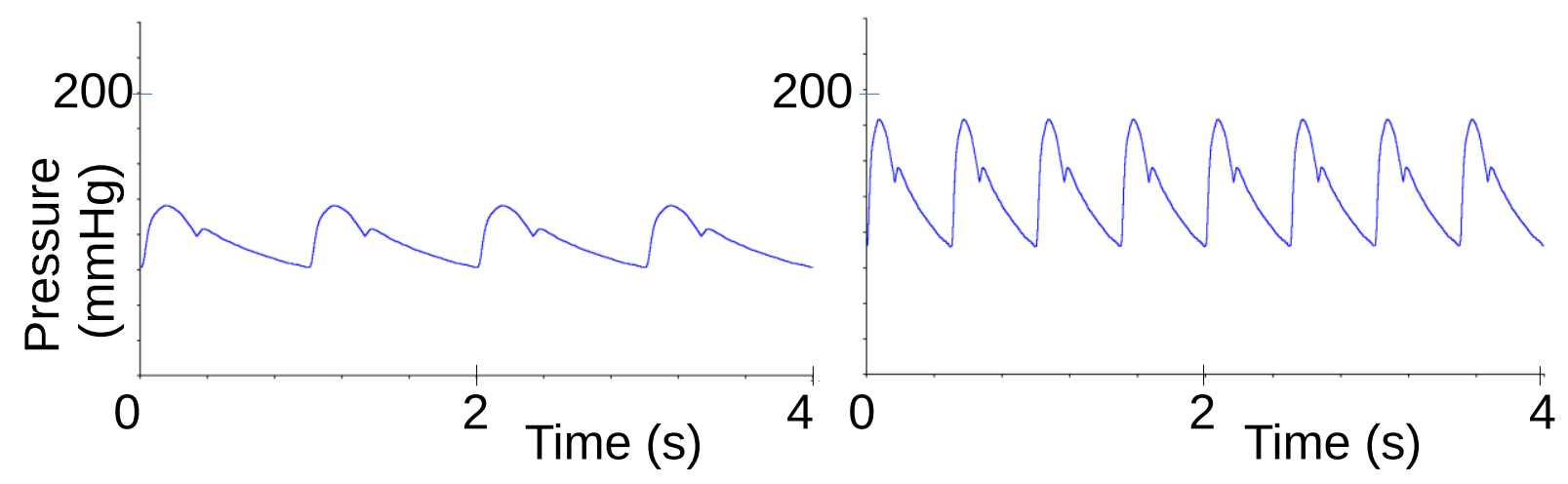

Figure 1. Synthesized arterial pressure waveform for (i) heart rate $=60 \mathrm{bpm}$, Systolic pressure $=120 \mathrm{mmHg}$ and Diastolic pressure $=76 \mathrm{mmHg}$, (ii) heart rate $=120 \mathrm{bpm}$, Systolic pressure $=$ $180 \mathrm{mmHg}$ and Diastolic pressure $=90 \mathrm{mmHg}$. 
medRxiv preprint doi: https://doi.org/10.1101/2020.08.29.20184275; this version posted October 25, 2020. The copyright holder for this preprint (which was not certified by peer review) is the author/funder, who has granted medRxiv a license to display the preprint in perpetuity.

All rights reserved. No reuse allowed without permission.

The frequency spectra of these two waveforms are shown in Figure 2. The spectrum consists of a zerofrequency component corresponding to the mean arterial pressure, a fundamental frequency corresponding to the heart rate and harmonics of the fundamental frequency - the amplitude of the harmonics depending on the specific shape of the arterial pressure waveform. The slow waveform's spectrum is almost completely less than $10 \mathrm{~Hz}$, while the fast waveform's spectrum extends noticeably above $15 \mathrm{~Hz}$. Any system that affects the spectra in the frequencies where significant components are present, will adversely affect the waveshape and consequently will increase the measurement error.
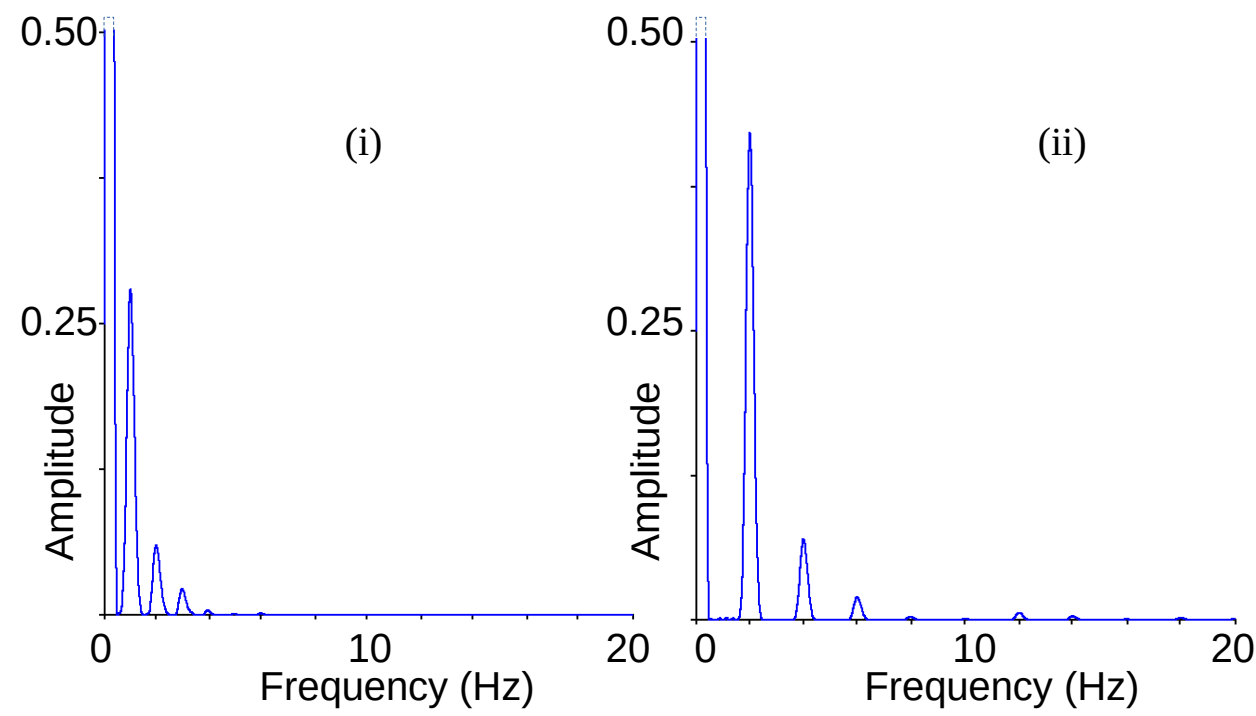

Figure 2. Frequency spectrum of (i) the slow waveform (60 bpm, 120/76 mmHg) and (ii) the fast waveform $(120 \mathrm{bpm}, 180 / 90 \mathrm{mmHg})$. In order to show the spectral components clearly the graphs have been magnified to the extent that the amplitude at zero frequency is off-scale.

\section{Estimation of the range of values for natural frequency and damping coefficient for the simulation of a second order system representing the measurement system:}

The dynamic characteristics of the measurement system can be studied in two ways, (a) using real data from patients with intra-arterial pressure measurement systems in place, by performing the Fast-flush test and calculating $f_{\text {natural }}$ and $Z_{\text {damping }}$ (b) simulating a fluid filled catheter of dimensions similar to the real one, having air bubbles of varying sizes, and estimating its $f_{\text {natural }}$ and $Z_{\text {damping }}$ with calculations. 
medRxiv preprint doi: https://doi.org/10.1101/2020.08.29.20184275; this version posted October 25, 2020. The copyright holder for this preprint (which was not certified by peer review) is the author/funder, who has granted medRxiv a license to display the preprint in perpetuity.

All rights reserved. No reuse allowed without permission.

Method 'a' gives us an idea of actual errors experienced in current clinical situations, and method ' $b$ ' allows us to anticipate errors due to the catheter and measurement setting and accordingly take corrective measures by choosing catheter material, catheter size, etc.

For the real-world scenario as in case (a), the Fast-flush test was performed on patients after obtaining informed consent and was recorded using a data acquisition system (CMCdaq). The patients already had intra-arterial catheters for blood pressure measurement as standard of care. The intra-arterial catheter and pressure transducer were undisturbed during routine recording, and the signal from the transducer was connected in parallel to CMCdaq. The study was approved by the Institutional Review Board of Christian Medical College Vellore, India (IRB Min. No: 10859 dated 27/09/2017 and 12173 dated 06/08/2019).

The $f_{\text {natural }}$ and $Z_{\text {damping }}$ were calculated from the recorded flush test. The applied input in the Fast-flush test is a step change from about $300 \mathrm{mmHg}$ to the mean arterial pressure, and the response to this is a damped oscillation about the final value which is approximately the mean arterial pressure (see Figure 3). 


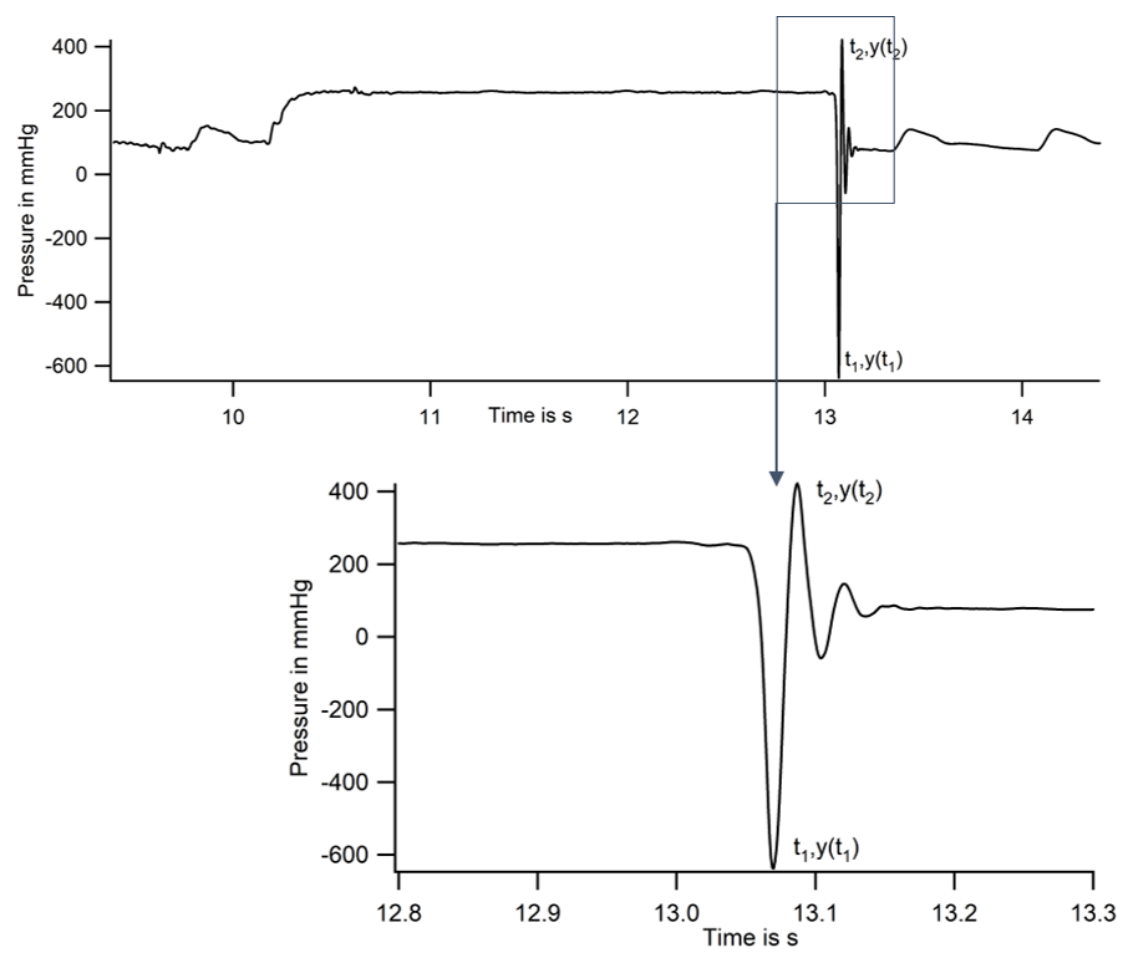

Figure 3. Recording of pressure changes during a Fast-flush test from a patient with an intra-arterial catheter.

By measuring the time, $t_{n}$, and amplitude swing, $y_{n}$, (deviation from the mean arterial pressure) of the $n^{\text {th }}$ maximum, the natural frequency and damping coefficient can be calculated (see Appendix for calculation of natural frequency, $f_{\text {natural }}$ and damping coefficient $Z_{\text {damping }}$ from the Fast-flush test waveform).

Analysis of 121 flush tests done in patients in a surgical ICU, showed that the interquartile range for $f_{\text {natural was }} 10-40 \mathrm{~Hz}$, and that for $Z_{\text {damping was }} 0-0.6$ (rounded off to the nearest first decimal value (Figures 4A and B)). Data from all 121 recordings are shown on Gardner's plot in Figure 4C. 

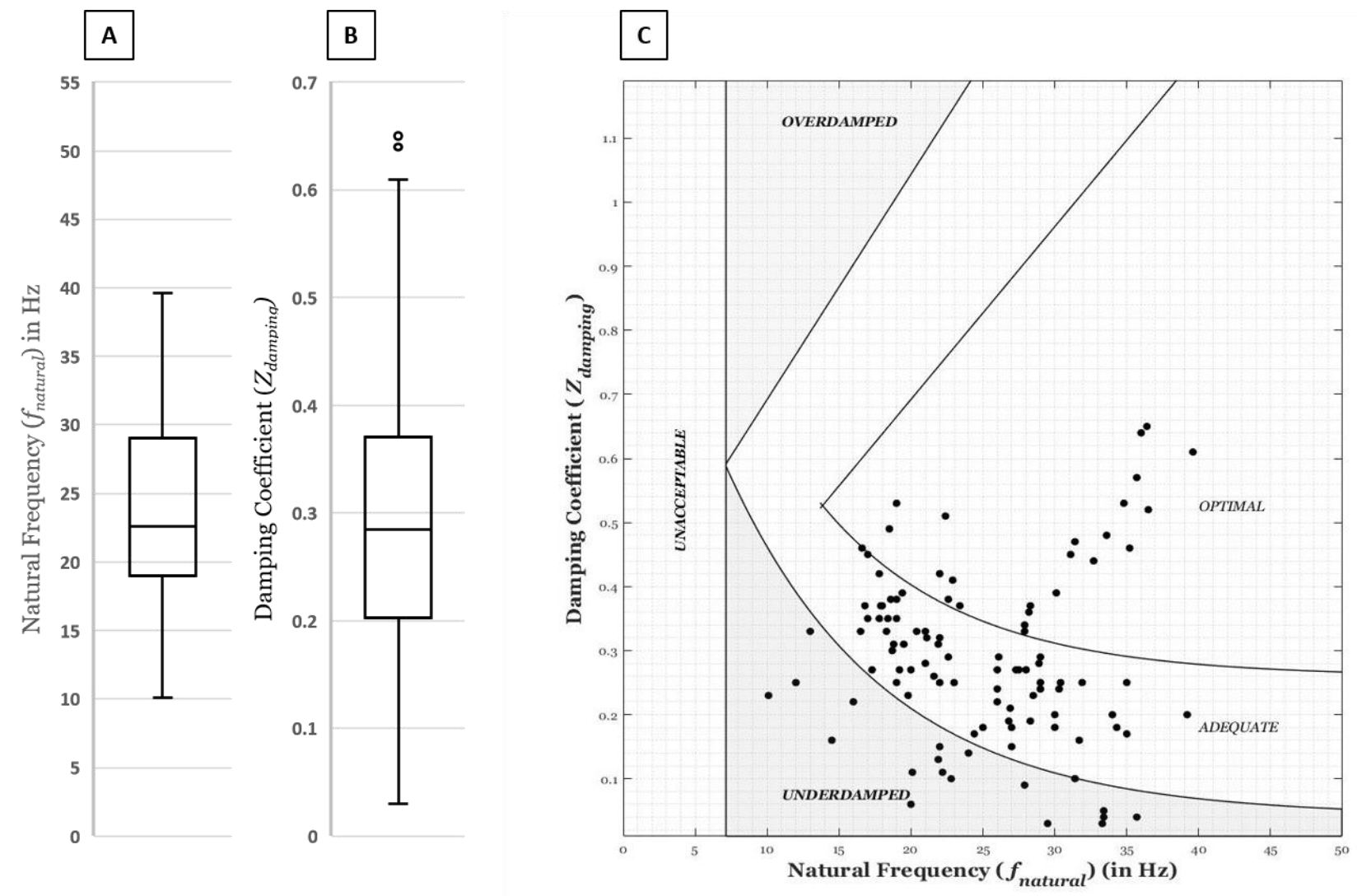

Figure 4. Box plots of (A) Natural Frequency and (B) Damping Coefficient measured with Fast-flush tests in 121 patients with intra-arterial catheters (C) values plotted on the original Gardner's Plot.

For the simulated catheter as in case ' $b$ ', the following values were used. The catheter radius, $r$ was set at $0.9 \mathrm{~mm}$, wall thickness $h$ at $0.2 \mathrm{~mm}$, modulus of elasticity $E_{\mathrm{c}}$ at $3 \times 10^{9} \mathrm{~Pa}$, and the length $l$ was varied from 200 to $2000 \mathrm{~mm}$. The elastance of the transducer diaphragm $E_{\mathrm{d}}$ was set at $0.5 \times 10^{15} \mathrm{Nm}^{-5}$. Air bubbles in the fluid could be assigned a volume ranging from 0 to $6 \mathrm{~mm}^{3}$. With these values for the catheter system, the calculated $f_{\text {natural }}$ varied in the range $10 \mathrm{~Hz}$ to $20 \mathrm{~Hz}$, and $Z_{\text {damping }}$ in the range 0.08 to 0.32 (see Appendix for calculation of catheter system characteristics). These values are within the range of what is recorded in patients as in case 'a'. These values of $f_{\text {natural }}$ and $Z_{\text {damping }}$ are also very similar to those reported in the literature (e.g., $12.5 \mathrm{~Hz}, 0.28,{ }^{12}$ ). 
medRxiv preprint doi: https://doi.org/10.1101/2020.08.29.20184275; this version posted October 25, 2020. The copyright holder for this preprint (which was not certified by peer review) is the author/funder, who has granted medRxiv a license to display the preprint in perpetuity.

All rights reserved. No reuse allowed without permission.

The values for $f_{\text {natural }}$ and $Z_{\text {damping }}$ of the pressure measurement system obtained by the above two methods, were used to simulate different virtual measurement systems with $0<f_{\text {natural }}<50 \mathrm{~Hz}, 0<Z_{\text {damping }}$ $<1.5$, so as to cover the full range of possible values of the measurement system parameters.

\section{Simulation}

For the slow and fast arterial pressure waveforms shown in Figure 1, the measurement system characteristics were varied, and the measurement error was calculated. The natural frequency was varied in the range $0 \mathrm{~Hz}$ to $50 \mathrm{~Hz}$ and the damping coefficient in the range 0 to 1.5 . This fully covers the values expected in the catheter-based measurement systems, with sufficient values above and below to cover all possible values in a real measurement system. The simulations used a sampling rate of 1000 samples/second.

\section{Measured pressure waveform}

The measured pressure wave is the result of passing the "true pressure wave" (simulated to have different systolic rise-rates by time and amplitude scaling) through the "measurement system" which is the virtual fluid-filled catheter in which $f_{\text {natural }}$ can be varied between 0 and $50 \mathrm{~Hz}$ and $Z_{\text {damping }}$ can be varied between 0 and 1.5 .

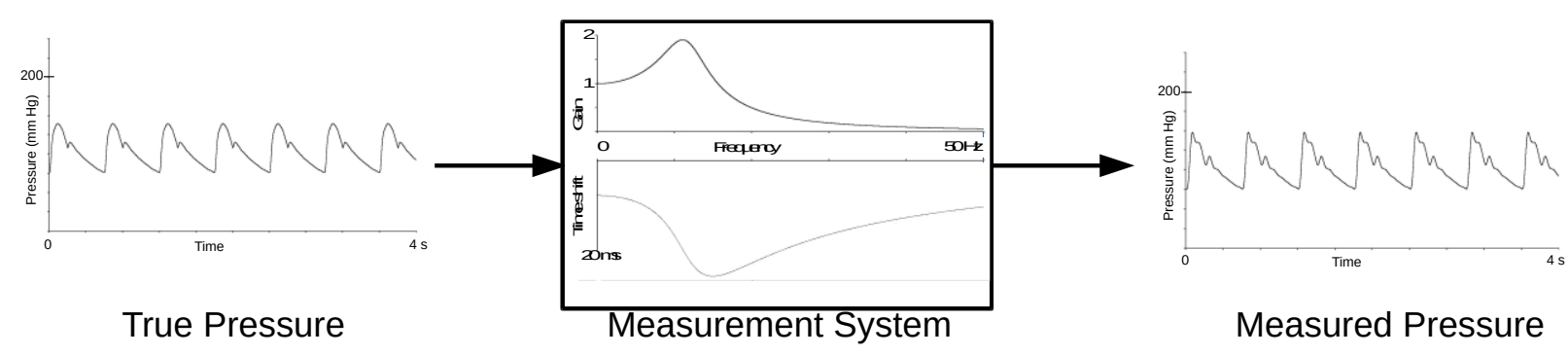

Figure 5. True Pressure passed through a measurement system yielding the Measured Pressure 
medRxiv preprint doi: https://doi.org/10.1101/2020.08.29.20184275; this version posted October 25, 2020. The copyright holder for this preprint (which was not certified by peer review) is the author/funder, who has granted medRxiv a license to display the preprint in perpetuity.

All rights reserved. No reuse allowed without permission.

Figure 5 shows the measured waveform on the right and the "true pressure waveform" on the left. The frequency response of the fluid-filled catheter measurement system is shown in the box in the middle.

The system response is plotted as gain in the upper panel and time shift in the lower panel, both plotted against frequency.

\section{Error calculation}

The error in the measurement was quantified by, (a) the mean error, (b) the systolic error and (c) diastolic error (see Appendix for formal algebraic definitions of the errors). 

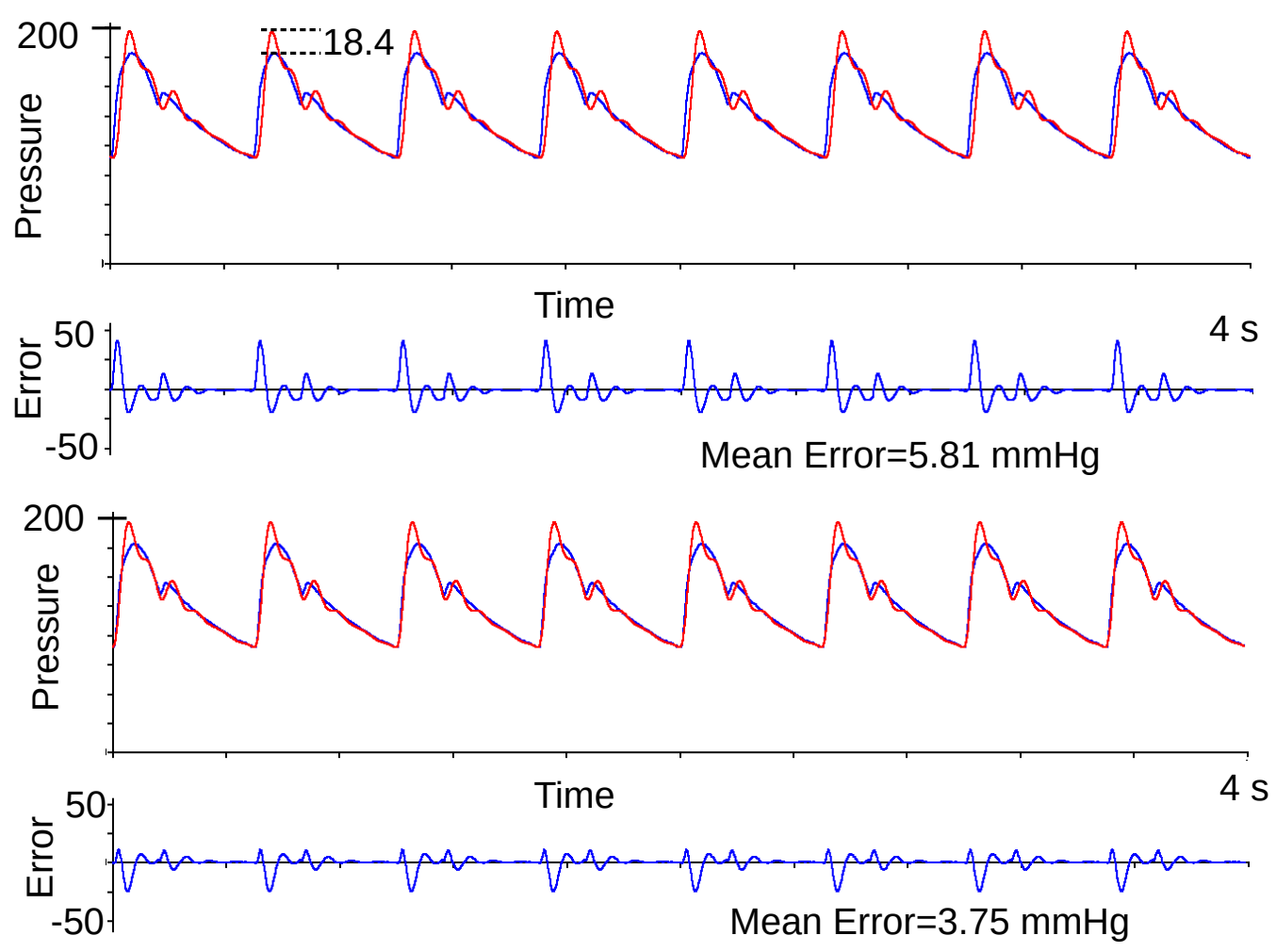

Figure 6. Overlaid pressure waveforms of the "true" pressure (blue) and the measured pressure (red). The lower panels show the waveforms time shifted to account for the measurement system's phase lag; the time shift is adjusted so that the pressure difference between the "true" and measured signals is minimized. The time shift is $12 \mathrm{~ms}$.

Figure 6 shows the true and measured waveforms overlaid and the instantaneous error, $\operatorname{error}(t)=P_{m}(t)-P_{i}(t)$, plotted on the same time scale (subscript ' $m$ ' is for the measured waveform and subscript ' $i$ ' for the true waveform). There is a time shift between the true waveform and the measured waveform. The top panels show the wave-forms without phase correction. The mean error is high (5.81 $\mathrm{mmHg}$ ) because of the phase shift. If the input waveform is shifted in time to synchronize with the measured pressure waveform, then the calculation of the mean error reflects more correctly the error as seen during an actual measurement. The time shifted waveforms, error $(t)=P_{m}(t)-P_{i}(t-\tau)$, are shown in 
medRxiv preprint doi: https://doi.org/10.1101/2020.08.29.20184275; this version posted October 25, 2020. The copyright holder for this preprint (which was not certified by peer review) is the author/funder, who has granted medRxiv a license to display the preprint in perpetuity.

All rights reserved. No reuse allowed without permission.

the lower panel of Figure 6. In this illustration the mean error after phase correction is $3.75 \mathrm{mmHg}$. The systolic error is $18.4 \mathrm{mmHg}$ in both cases and the diastolic error, $-0.1 \mathrm{mmHg}$.

\section{Correcting the Measurement System Using Filters}

When the system transfer function of the measurement system has a corner frequency or natural frequency that is too low and a damping coefficient that is sub-optimal for that natural frequency, then the measured signal is a degraded form of the true pressure waveform. We can add a compensating filter to correct the characteristics of the measurement system, to make the overall system frequency response flat in the bandwidth of interest. The bandwidth of interest is $0-30 \mathrm{~Hz}$. While it may be difficult to make the frequency response absolutely flat in this band, we can make it very nearly flat by having a compensating filter. Some examples of such filters and their pros and cons are also discussed later.

\section{Results}

We chose 3 hypothetical measurement systems for detailed simulations of measurement of the two input waveforms, slow and fast. Figure 7 shows the calculated waveforms for the Fast-flush test response of measurement systems with the combinations of $f_{\text {natural }}$ and $Z_{\text {damping }}$ as (i) $12 \mathrm{~Hz} ; 0.25$ (ii) $20 \mathrm{~Hz}$; 0.25 and (iii) $20 \mathrm{~Hz}$; 0.4. The suggested quality assessment of the Fast-flush test in the clinical setting is that there should be no more than 2 oscillations, and the time interval between oscillations should be less than 30 ms. Viewing Figure 7 with this set of criteria, it can be said that the three selected virtual measuring systems do not quite meet these criteria. However, they were chosen because (a) they represent the range of poor and marginal to acceptable category in Gardner's plot, thereby illustrating both poor and acceptable waves, and (b) a sizable fraction of our 121 Fast-flush tests recorded had values for $f_{\text {natural }}$ and $Z_{\text {damping }}$ in the range chosen (see Figures $4 \mathrm{~A}$ and $\mathrm{B}$ ) and values reported in the literature more often than not, fall in this range ${ }^{12}$. 


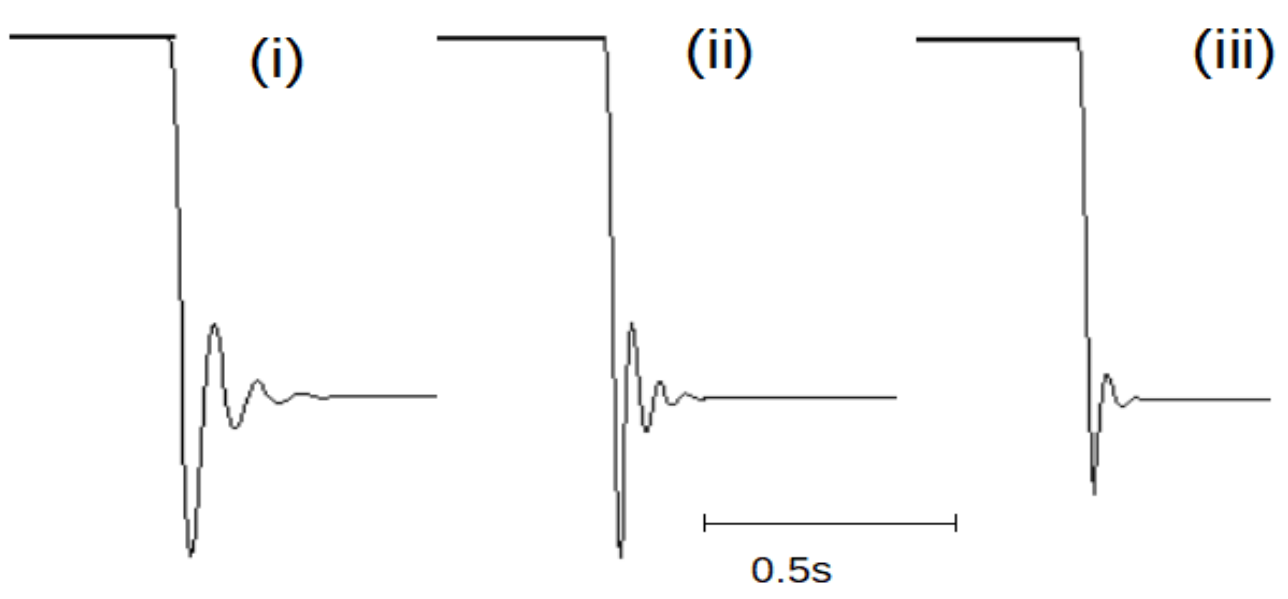

Figure 7. Step response (Fast-flush test) of a system with (i) $\mathrm{f}_{\text {natural }}=12 \mathrm{~Hz}, \mathrm{Z}_{\text {damping }}=0.25$, (ii) $\mathrm{f}_{\text {natural }}=20 \mathrm{~Hz}, \mathrm{Z}_{\text {damping }}=0.25$, (iii) $\mathrm{f}_{\text {natural }}=20 \mathrm{~Hz}, \mathrm{Z}_{\text {damping }}=0.4$. About $500 \mathrm{~ms}$ of each waveform is shown.

Figure 8 shows the result of the slow pressure waveform and the fast pressure waveform when passed through a measurement system with $f_{\text {natural }}=12 \mathrm{~Hz}$ and $Z_{\text {damping }}=0.25$. The "true" waveform is shown in blue and the measured waveform in red. The slow waveform shown on the left in Figure 8 undergoes a slight change in shape but the mean error, systolic error and diastolic error are not very large. The fast waveform on the right in Figure 8 undergoes a substantial change with the systolic error being as large as $18.4 \mathrm{mmHg}$. 


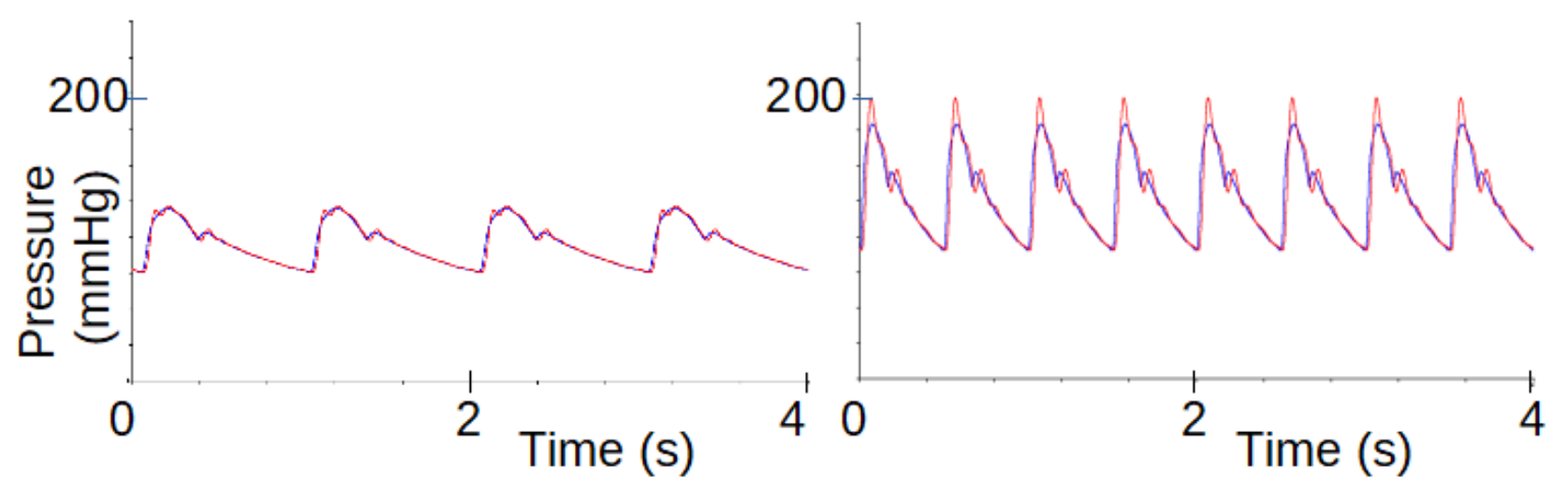

Figure 8. System characteristics, $\mathrm{f}_{\text {natural }}=12 \mathrm{~Hz}, \mathrm{Z}_{\text {damping }}=0.25$. (i) Mean error $=0.73 \mathrm{mmHg}$, Systolic error $=1.6 \mathrm{mmHg}$, Diastolic error $=-0.3 \mathrm{mmHg}$, Time shift $=10 \mathrm{~ms}$ (was corrected), (ii) Mean error $=3.76 \mathrm{mmHg}$, Systolic error $=18.4 \mathrm{mmHg}$, Diastolic error $=-0.1 \mathrm{mmHg}$. Time shift $=12 \mathrm{~ms}($ was corrected).

If the bandwidth of the measurement system is improved to have a higher natural frequency with $f_{\text {natural }}$ $=20 \mathrm{~Hz}$ and $Z_{\text {damping }}=0.25$, then the measured signal is considerably improved. Figure 9 shows the result of the slow pressure waveform and the fast pressure waveform when passed through such a system. The slow waveform shown on the left has the red and blue traces almost exactly overlaying each other. The fast waveform shown on the right shows some degradation but is better than in the earlier case; the systolic error is only $3.1 \mathrm{mmHg}$. 


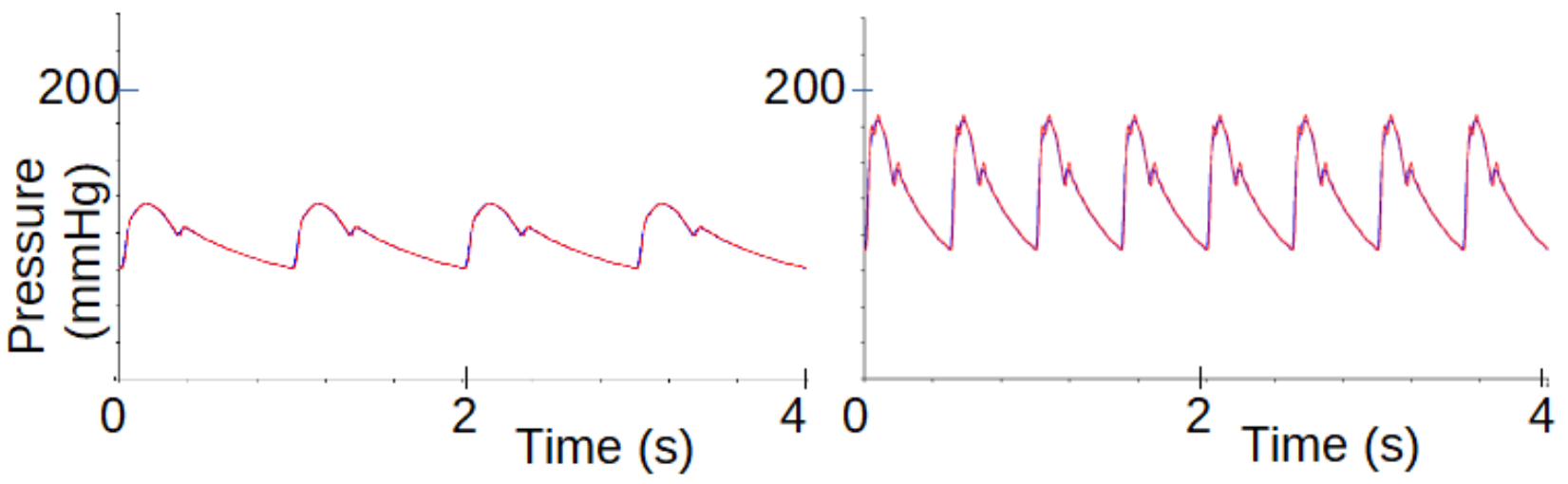

Figure 9. System characteristics, $\mathrm{f}_{\text {natural }}=20 \mathrm{~Hz}, \mathrm{Z}_{\text {damping }}=0.25$, (i) Mean error $=0.28 \mathrm{mmHg}$, Systolic error $=0.2 \mathrm{mmHg}$, Diastolic error $=-0.2 \mathrm{mmHg}$, Time shift $=4 \mathrm{~ms}$ (was corrected) (ii) Mean error $=$ $1.4 \mathrm{mmHg}$, Systolic error $=3.1 \mathrm{mmHg}$, Diastolic error $=-0.5 \mathrm{mmHg}$, Time shift $=4 \mathrm{~ms}$ (was corrected).

If the damping of the system is increased and we have a system with $f_{\text {natural }}=20 \mathrm{~Hz}$ and $Z_{\text {damping }}=0.40$, then the measured signal is further improved. Figure 10 shows the two waveforms passed through this system. Both the slow and fast waveforms pass through the system very well. There is a barely visible distortion of the fast waveform and none in the slow waveform.

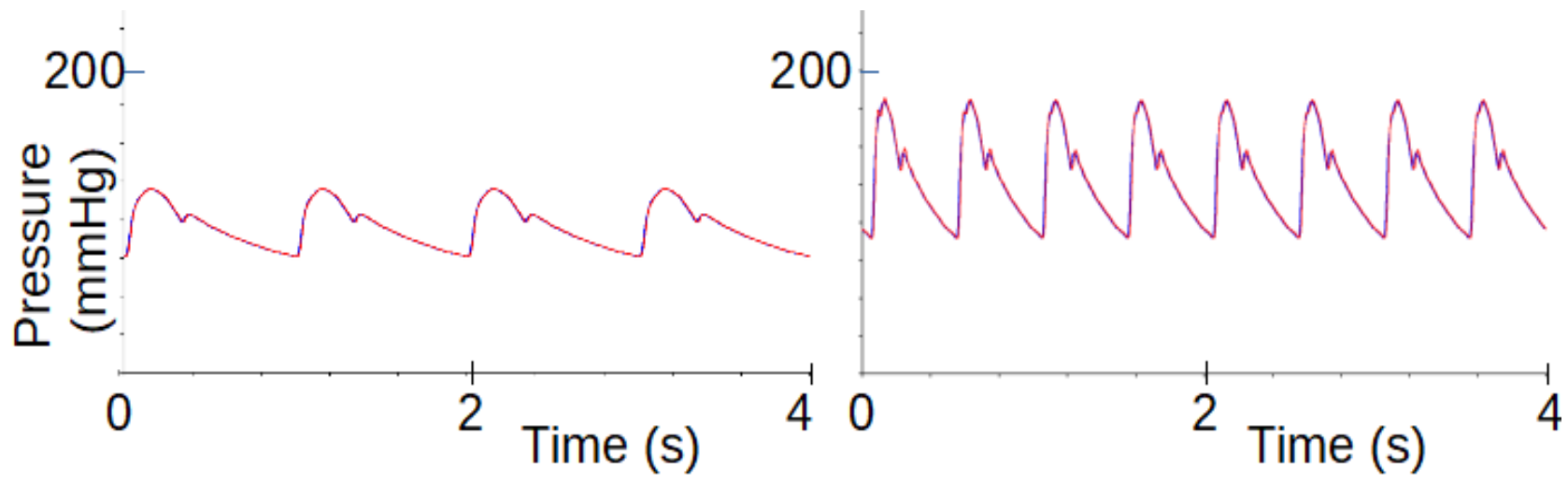

Figure 10. System characteristic, $\mathrm{f}_{\text {natural }}=20 \mathrm{~Hz}, \mathrm{Z}_{\text {damping }}=0.40$. (i) Mean error $=0.12 \mathrm{mmHg}$, Systolic error $=0 \mathrm{mmHg}$, Diastolic error $=-0.1 \mathrm{mmHg}$, Delay $=5 \mathrm{~ms}$, (ii) Mean error $=0.83 \mathrm{mmHg}$, Systolic error $=1.0 \mathrm{mmHg}$, Diastolic error $=-0.2 \mathrm{mmHg}$, Time shift $=5 \mathrm{~ms}$ (was corrected). 
medRxiv preprint doi: https://doi.org/10.1101/2020.08.29.20184275; this version posted October 25, 2020. The copyright holder for this preprint (which was not certified by peer review) is the author/funder, who has granted medRxiv a license to display the preprint in perpetuity.

All rights reserved. No reuse allowed without permission.

The effect of the system characteristics on the mean error in the case of the slow waveform (60 bpm, $120 / 76 \mathrm{mmHg}$ ) for various combinations of $f_{\text {natural }}$ and $Z_{\text {damping }}$ is summarized in Figure 11 as a colored heat-map. The red regions are where the combination of $f_{\text {natural }}$ and $Z_{\text {damping }}$ yield mean error values greater than $8 \mathrm{mmHg}$. This red region includes errors that are as much as $100 \mathrm{mmHg}$ when the $f_{\text {natural }}$ is very low and the $Z_{\text {damping }}$ is also very low. The yellow and green regions have errors that are too high for comfort. The blue regions indicate areas where the error is marginally acceptable. The purple region is where the error is acceptably small. In this region the $f_{\text {natural }}$ is above $5 \mathrm{~Hz}$. If the $Z_{\text {damping }}$ is outside a narrow range around 0.6 , then the $f_{\text {natural }}$ must be above $10 \mathrm{~Hz}$. The dot plots in Figures $11-14$ are the results of 121 flush tests reported earlier in this paper.

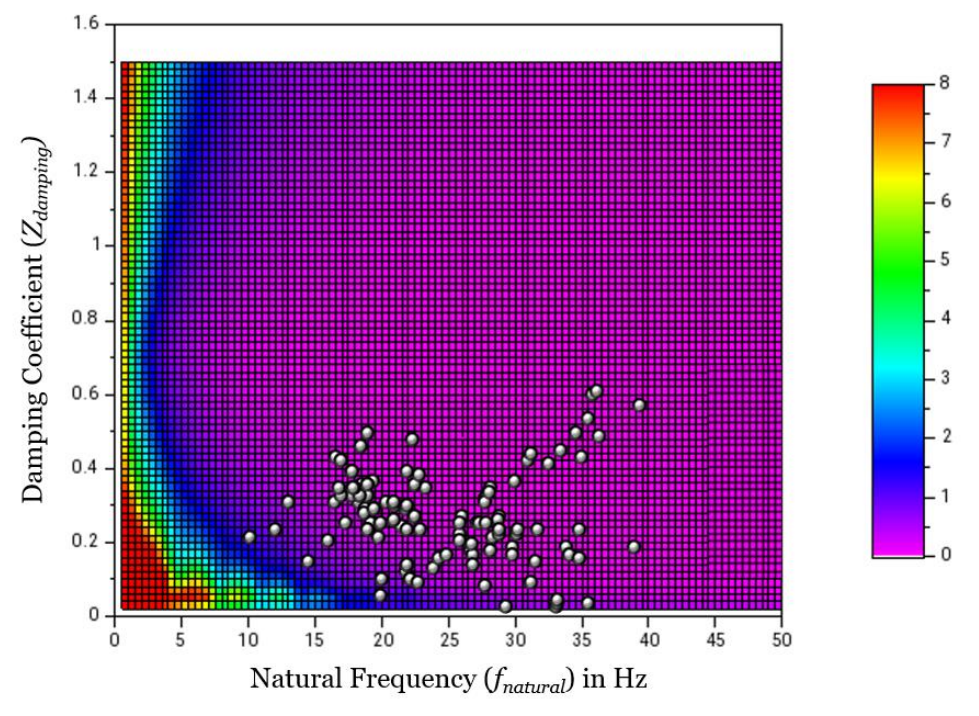

Figure 11. Mean Error shown as a heat map in Gardner's plot ( $\left.Z_{\text {damping versus }} f_{\text {natural }}\right)$ for a systolic pressure rise-rate $=300 \mathrm{mmHg} / \mathrm{s}$. The dot plots represent real values from 121 patients.

In the case of the fast waveform $(120 \mathrm{bpm}, 180 / 90 \mathrm{mmHg})$ the system requirement becomes more stringent. Figure 12 shows a heat-map of the mean error plotted for different values of $f_{\text {natural }}$ and $Z_{\text {damping. }}$. For the mean error to be acceptably small, below $1.5 \mathrm{mmHg}$, the $f_{\text {natural }}$ must be at least $15 \mathrm{~Hz}$. When the 
medRxiv preprint doi: https://doi.org/10.1101/2020.08.29.20184275; this version posted October 25, 2020. The copyright holder for this preprint (which was not certified by peer review) is the author/funder, who has granted medRxiv a license to display the preprint in perpetuity.

All rights reserved. No reuse allowed without permission.

$Z_{\text {damping }}$ is outside the narrow band around 0.6 , the $f_{\text {natural }}$ must be even higher. The blue band in Figure 12 corresponds very closely to the boundary shown in Figure 5 of Gardner, $1981^{3}$.

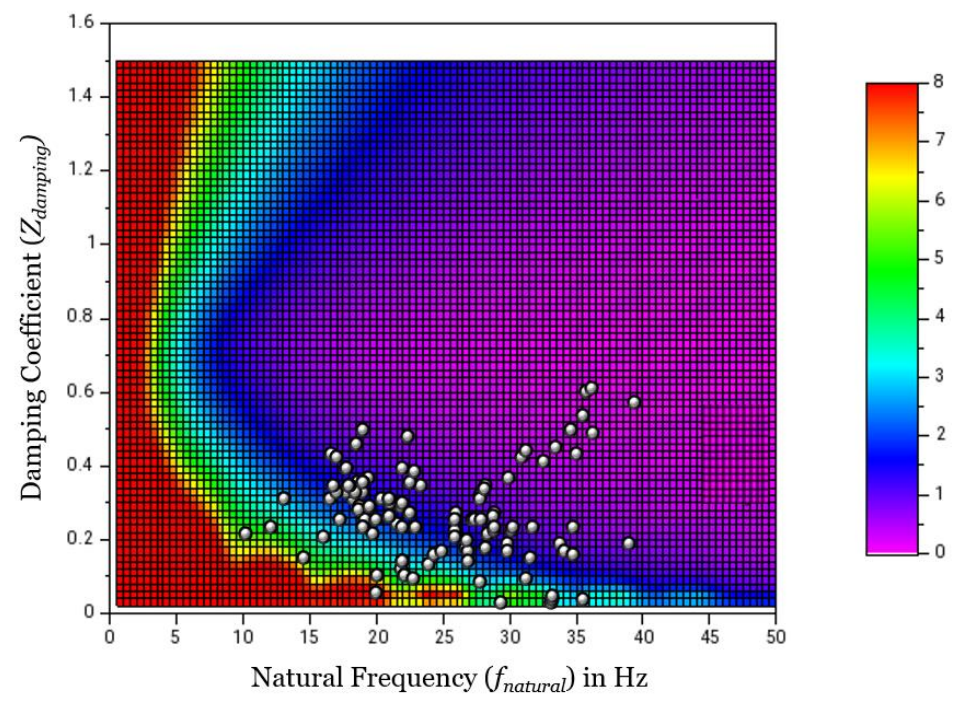

Figure 12. Mean Error shown as a heat map in Gardner's plot $\left(Z_{\text {damping versus }} f_{\text {natural }}\right)$ for a systolic pressure rise-rate $=1200 \mathrm{mmHg} / \mathrm{s}$. The dot plots represent real values from 121 patients.

The mean error of measurement does not give the full picture of the problem with blood pressure measurement, as it is possible to have a combination of positive and negative errors resulting in small mean error. Therefore, we have calculated the systolic error also for the various combinations of $f_{\text {natural }}$

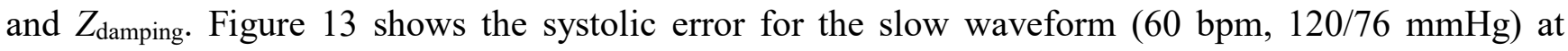

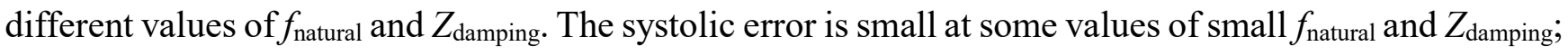
this is likely to be a coincidental agreement in the waveform peaks even though the measured waveform is considerably distorted. The correct way to look at the error maps is to consider both the mean error and systolic error together (i.e., consider them superimposed with an AND operation), and only the regions where both mean error and systolic error are less than $3 \mathrm{mmHg}$ should be considered acceptable. 
medRxiv preprint doi: https://doi.org/10.1101/2020.08.29.20184275; this version posted October 25, 2020. The copyright holder for this preprint (which was not certified by peer review) is the author/funder, who has granted medRxiv a license to display the preprint in perpetuity.

All rights reserved. No reuse allowed without permission.

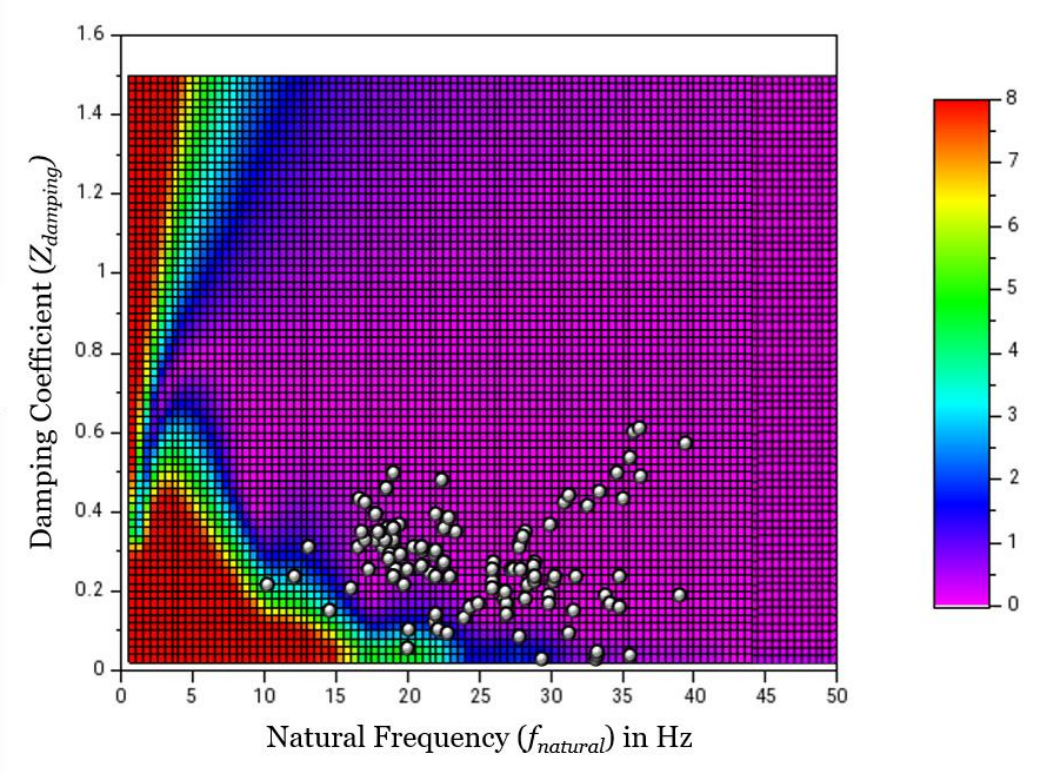

Figure 13. Systolic Error shown as a heat map in Gardner's plot ( $Z_{\text {damping versus }} f_{\text {natural }}$ ) for a systolic pressure rise-rate $=300 \mathrm{mmHg} / \mathrm{s}$. The dot plots represent real values from 121 patients.

The systolic error in the case of the fast waveform has an even smaller acceptable region as shown in Figure 14. From the systolic error and mean error maps for the fast waveform we see that the system should have $f_{\text {natural }}$ greater than $15 \mathrm{~Hz}$ and $Z_{\text {damping }}$ between 0.4 and 0.9 to have acceptable levels of error. Here too, there can be some situations where coincidentally, the systolic error is small although the waveshape is poor - these are the blue and violet regions below $f_{\text {natural }}$ of $10 \mathrm{~Hz}$. 
medRxiv preprint doi: https://doi.org/10.1101/2020.08.29.20184275; this version posted October 25, 2020. The copyright holder for this preprint (which was not certified by peer review) is the author/funder, who has granted medRxiv a license to display the preprint in perpetuity.

All rights reserved. No reuse allowed without permission.
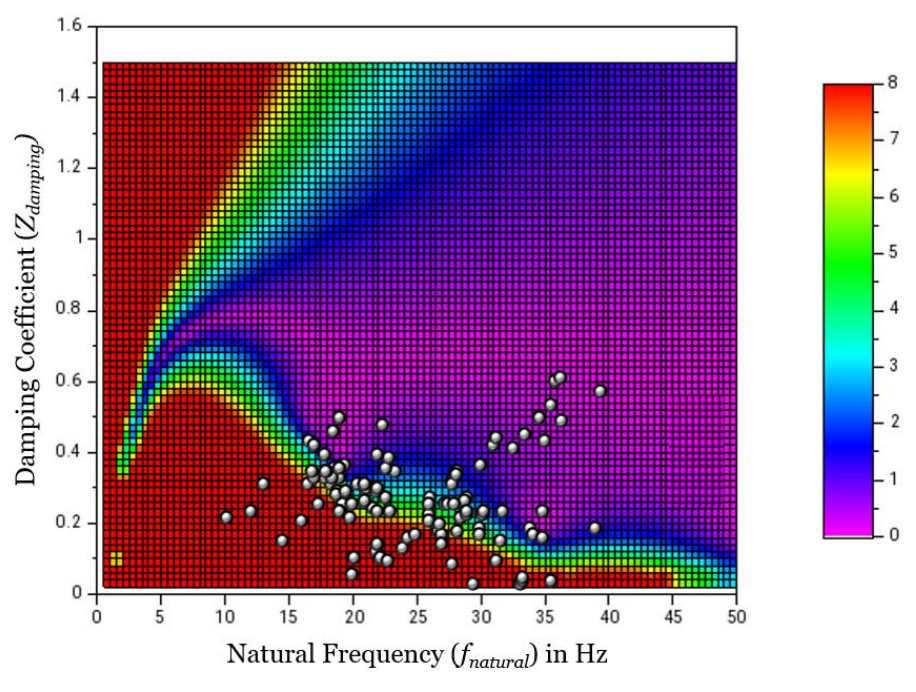

Figure 14. Systolic Error shown as a heat map in Gardner's plot ( $\left.Z_{\text {damping versus }} f_{\text {natural }}\right)$ for a systolic pressure rise-rate $=1200 \mathrm{mmHg} / \mathrm{s}$. The dot plots represent real values from 121 patients.

In all these graphs, the red regions encompass a large range of errors from $8 \mathrm{mmHg}$ to over $100 \mathrm{mmHg}$, and therefore, these regions must be avoided at all cost - the resulting pressure measurement is simply meaningless.

From the plots of the $f_{\text {natural }}$ and $Z_{\text {damping }}$ obtained from 121 patients shown in the heat maps as above, it is obvious that in a significant proportion of patients, the points fall in the red region of Figure 14, and therefore, the systolic error, if the heart rate was high would have been unacceptably high. In such situations, where no more physical alterations could be made to the recording system, like reduction of the length of the catheter tubing, removal of air bubble etc., it is desirable to have a way of correcting for errors in pressure measurement, say, by way of a compensating filter, which is discussed in the next section.

The diastolic error is smaller than the mean error and the systolic error and is not shown here. The mean error is presumably the quality measure used in the paper by Gardner ${ }^{3}$ although it is not clearly stated in that paper. 
medRxiv preprint doi: https://doi.org/10.1101/2020.08.29.20184275; this version posted October 25, 2020. The copyright holder for this preprint (which was not certified by peer review) is the author/funder, who has granted medRxiv a license to display the preprint in perpetuity.

All rights reserved. No reuse allowed without permission.

\section{Using a Compensating Filter}

When a compensating filter is used to correct the measurement system characteristics it is necessary to know the actual characteristics of the measurement system. In the next four figures we show how important is knowledge of the actual measurement system characteristics to apply a compensating filter. Figure 15 shows the use of a compensating filter. The system has $f_{\text {natural }}$ of $20 \mathrm{~Hz}$ and $Z_{\text {damping }}$ of 0.25 , and when the arterial pressure waveform is passed through it, we obtain the measured waveforms shown in Figure 9. In order to obtain a nearly flat frequency response in the band $0-20 \mathrm{~Hz}$, we add a compensating filter with $f_{\text {natural }}$ of $30 \mathrm{~Hz}$ and $Z_{\text {damping }}$ of 1.5 . The frequency spectra are shown in the left of Figure 15 and the measured waveforms are shown on the right. The measured waveforms are quite good reproductions of the true waveforms, and the calculated errors for both the slow and the fast waveforms are acceptably small. 

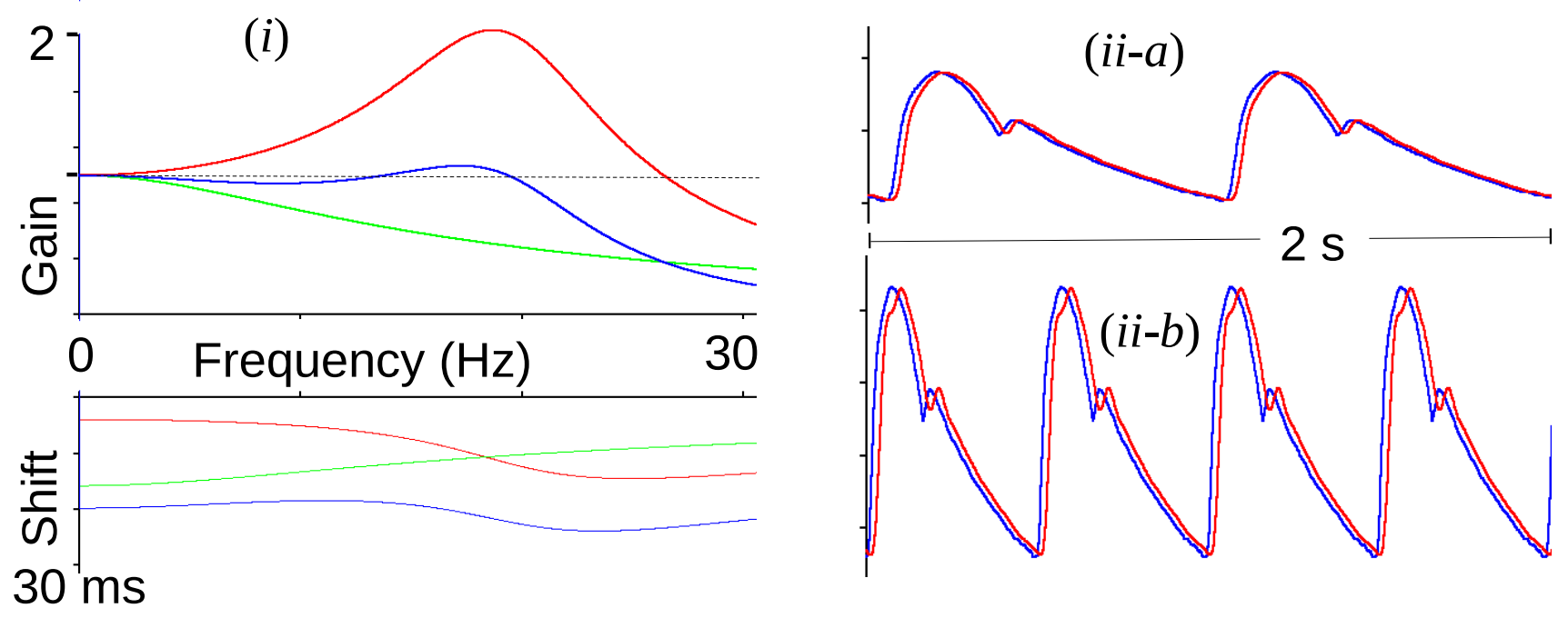

Figure 15. (i) Gain and time shift Vs frequency: spectrum of measurement system (red): $\mathrm{f}_{\text {natural }}=20 \mathrm{~Hz}$, $\mathrm{Z}_{\text {damping }}=0.25$. Spectrum of the compensating filter (green), $\mathrm{f}_{\text {natural }}=30 \mathrm{~Hz}, \mathrm{Z}_{\text {damping }}=1.5$, and spectrum of the cumulative system (blue). The dotted line in the gain graph shows the desired flat response with gain $=1$.

(ii) Slow and fast pressure waves passed through the system: blue $=$ true waveform, red $=$ measured waveform. (ii-a) Mean error $=0.1 \mathrm{mmHg}$, Systolic error $=-0.2 \mathrm{mmHg}$, Diastolic error $=0.1 \mathrm{mmHg}$; Time shift $=19 \mathrm{~ms}$, (ii-b) Mean error $=0.8 \mathrm{mmHg}$, Systolic error $=-0.5 \mathrm{mmHg}$, Diastolic error $=0.9 \mathrm{mmHg}$; Time shift $=19 \mathrm{~ms}$ (was corrected).

If the same compensating filter is permanently incorporated in the measurement system, and during the actual measurement the $f_{\text {natural }}$ of the catheter system is $12 \mathrm{~Hz}$, then we find that the compensating filter does not have the desired salutary effect, Figure 16. The errors for the slow waveforms are not much affected, but the fast waveform shows unacceptably large errors. 

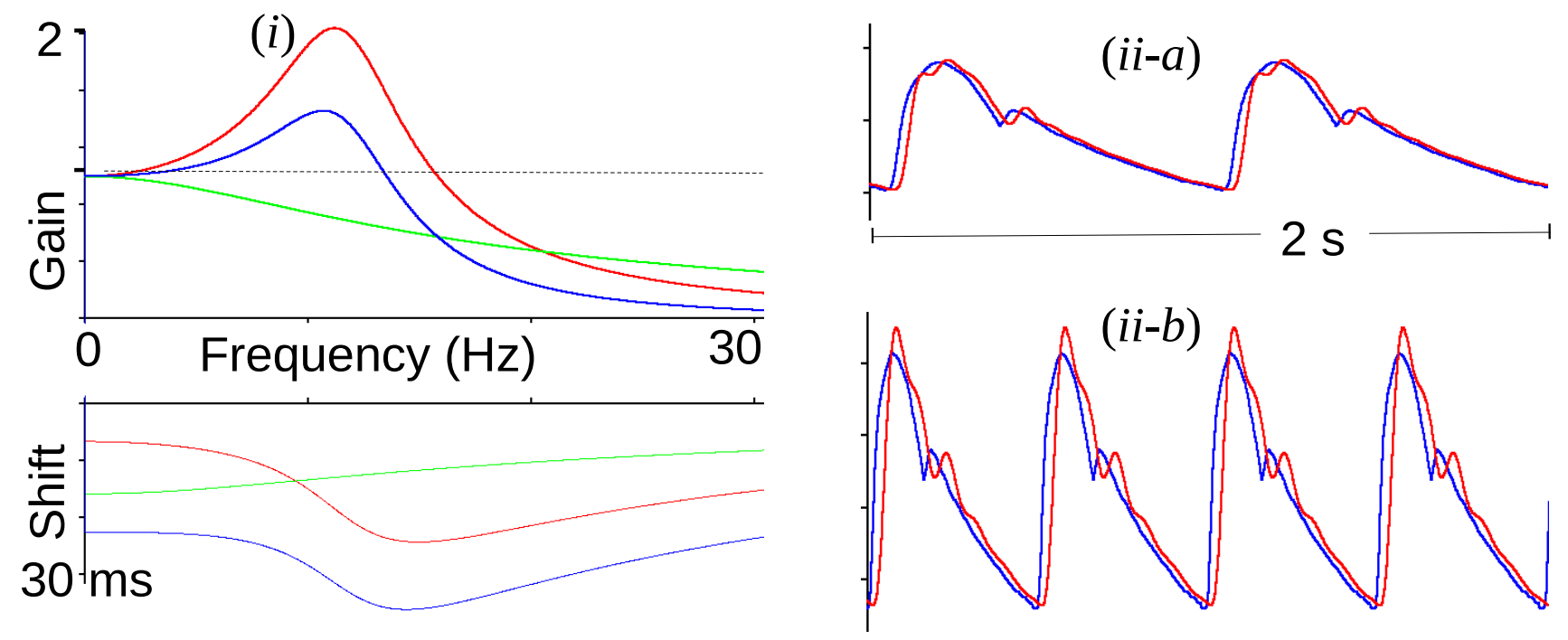

Figure 16. (i) Gain and time shift Vs frequency, i.e., spectra of measurement system (red): $\mathrm{f}_{\text {natural }}=$ $12 \mathrm{~Hz}, \mathrm{Z}_{\text {damping }}=0.25$. Compensating filter (green), $\mathrm{f}_{\text {natural }}=30 \mathrm{~Hz}, \mathrm{Z}_{\text {damping }}=1.5$, and the cumulative system (blue). The dotted line in the gain graph shows the desired flat response with gain $=1$.

(ii) Slow and fast pressure waves passed through the system: blue = true waveform, red $=$ measured waveform. (ii-a) Mean error $=0.4 \mathrm{mmHg}$, Systolic error $=0.9 \mathrm{mmHg}$, Diastolic error $=0 \mathrm{mmHg}$; Time shift $=24 \mathrm{~ms}$, (ii-b) Mean error $=2.3 \mathrm{mmHg}$, Systolic error $=9.0 \mathrm{mmHg}$, Diastolic error $=1.2$ $\mathrm{mmHg}$; Time shift $=24 \mathrm{~ms}$ (was corrected).

If the compensating filter is adjusted to have a lower cutoff frequency, then it can compensate for the lower resonance frequency of the measurement system. Figure 17 shows the measurement system with $f_{\text {natural }}$ of $12 \mathrm{~Hz}$ and $Z_{\text {damping }}$ of 0.25 with which a compensating filter with cutoff frequency $18 \mathrm{~Hz}$ and $Z_{\text {damping }}$ of 1.5 is used. The overall frequency response is reasonably flat to about $12 \mathrm{~Hz}$. The slow and fast waveforms passed through this system and compensating filter have reasonable measured waveforms. 

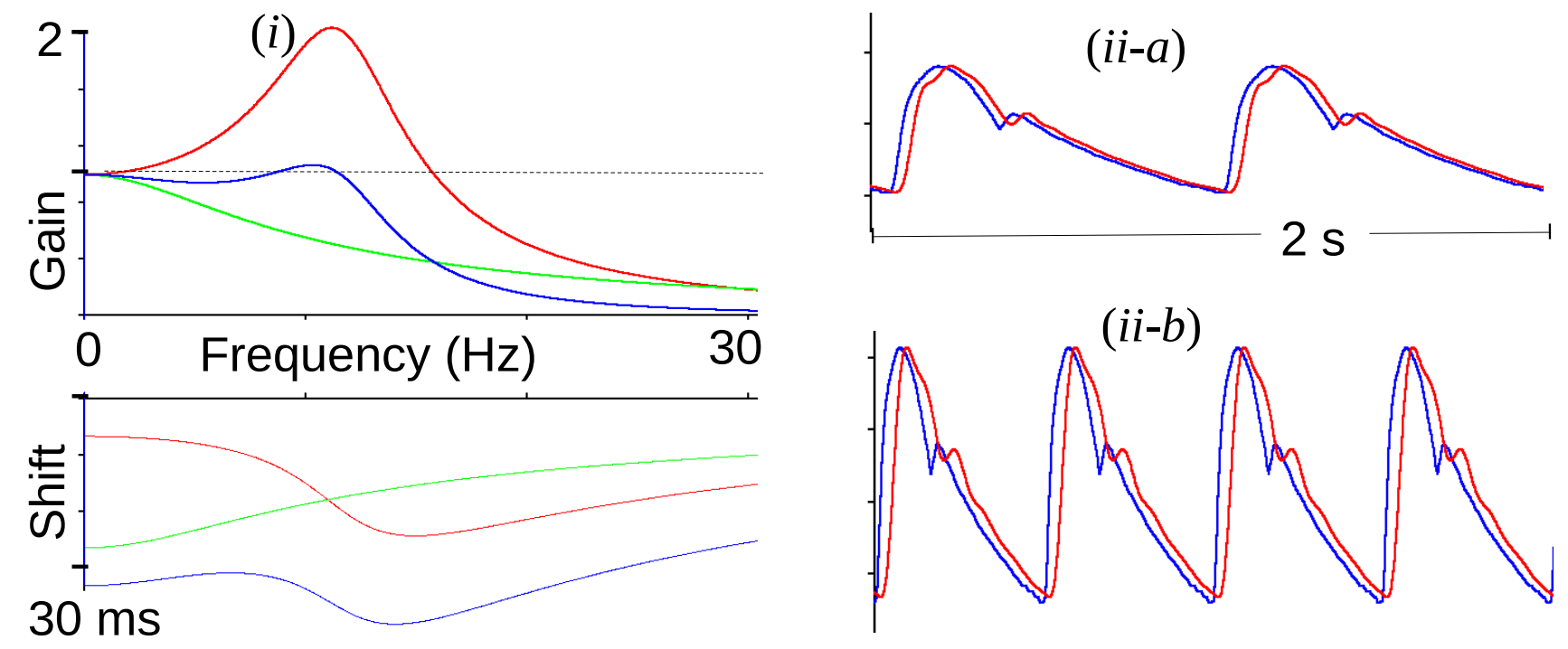

Figure 17. (i) Gain and time shift Vs frequency, i.e., spectra of measurement system (red): $\mathrm{f}_{\text {natural }}=12$ $\mathrm{Hz}, \mathrm{Z}_{\text {damping }}=0.25$. Compensating filter (green), $\mathrm{f}_{\text {natural }}=18 \mathrm{~Hz}, \mathrm{Z}_{\text {damping }}=1.5$, and the cumulative system (blue). The dotted line in the gain graph shows the desired flat response with gain $=1$.

(ii) Slow and fast pressure waves passed through the system: blue = true waveform, red = measured waveform. (ii-a) Mean error $=0.27 \mathrm{mmHg}$, Systolic error $=0.1 \mathrm{mmHg}$, Diastolic error $=0.3 \mathrm{mmHg}$; Time shift $=32 \mathrm{~ms}$ (was corrected), (ii-b) Mean error $=1.6 \mathrm{mmHg}$, Systolic error $=0.1 \mathrm{mmHg}$, Diastolic error $=2.1 \mathrm{mmHg}$; Time shift $=32 \mathrm{~ms}$ (was corrected).

Finally, in Figure 18, we demonstrate that using a compensating filter with a low bandwidth having $f_{\text {natural }}$ of $18 \mathrm{~Hz}$ and $Z_{\text {damping }}$ of 1.5 will not work when the measurement system has the wider bandwidth of $20 \mathrm{~Hz} f_{\text {natural }}$ and $1.5 Z_{\text {damping. }}$ 


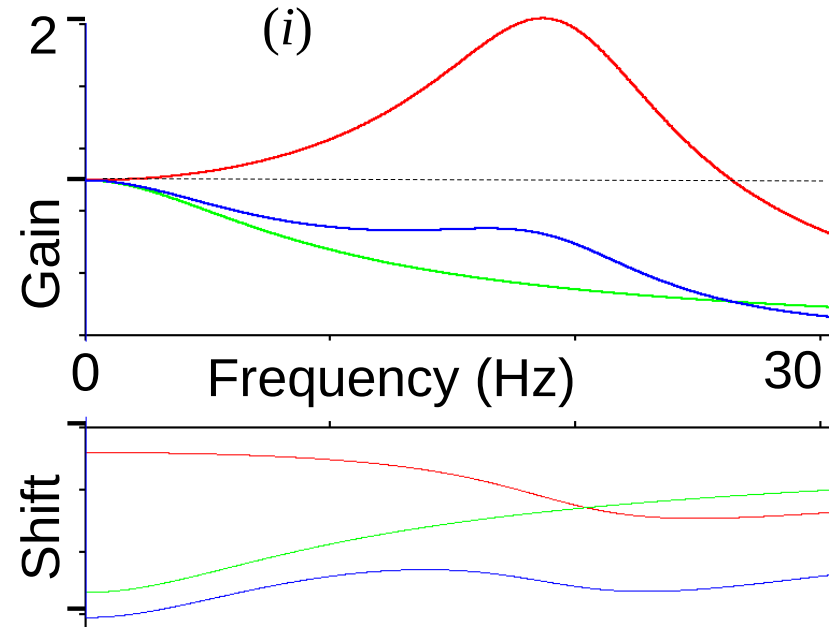

$30 \mathrm{~ms}$
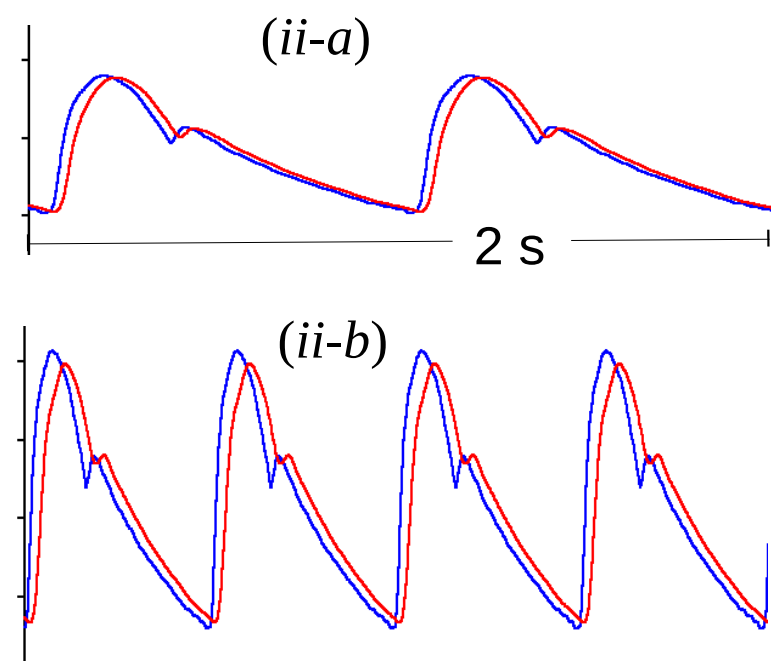

Figure 18. (i) Gain and time shift Vs frequency, i.e., spectra of measurement system (red): $\mathrm{f}_{\text {natural }}=20$ $\mathrm{Hz}, \mathrm{Z}_{\text {damping }}=0.25$. Compensating filter (green), $\mathrm{f}_{\text {natural }}=18 \mathrm{~Hz}, \mathrm{Z}_{\text {damping }}=1.5$, and the cumulative system (blue). The dotted line in the gain graph shows the desired flat response with gain $=1$.

(ii) Slow and fast pressure waves passed through the system: blue $=$ true waveform, red $=$ measured waveform. (ii-a) Mean error $=0.39 \mathrm{mmHg}$, Systolic error $=-0.7 \mathrm{mmHg}$, Diastolic error $=0.3 \mathrm{mmHg}$; Time shift $=29 \mathrm{~ms}$ (was corrected), (ii-b) Mean error $=1.9 \mathrm{mmHg}$, Systolic error $=-4.1 \mathrm{mmHg}$, Diastolic error $=1.9 \mathrm{mmHg}$; Time $\operatorname{shift}=29 \mathrm{~ms}$ (was corrected).

\section{Summary of the pressure measurement errors}

The four combinations of measurement systems and compensating filters is summarized in the Table 1. It is evident that a fixed filter will not work well if the system response is different from what the filter was designed for.

\section{Discussion}

We have shown by virtual experiments under a wide variety of conditions that the accurate measurement of intra-arterial blood pressure depends crucially upon the quality of the fluid-filled catheter pressure measurement system. Factors like the elasticity of the catheter material and that of the connecting tubing, catheter and tubing dimensions, especially length, inadvertent introduction of air bubbles into the catheter, etc., all adversely affect the measurement. Even apparently good measurement conditions that yield good pressure measurement can give highly inaccurate pressure measurement when the heart rate 
medRxiv preprint doi: https://doi.org/10.1101/2020.08.29.20184275; this version posted October 25, 2020. The copyright holder for this preprint (which was not certified by peer review) is the author/funder, who has granted medRxiv a license to display the preprint in perpetuity.

All rights reserved. No reuse allowed without permission.

or pulse pressure amplitude increases. The errors due to such measurement flaws alone can be as high as $18 \mathrm{mmHg}$ or more, in the systolic pressure. Such errors can lead to wrong interpretation of the cardiovascular status, erroneous calculations, and subsequently incorrect treatment. We have simulated the fluid-filled catheter pressure measurement system of blood pressure measurement and have shown that a poor frequency system response can result in very large errors of measurement.

The solution we propose to compensate for the poor characteristics of the measurement system is to use a post-measurement filter. Such a filter must be adjusted to match the requirement of the measurement system. Any fixed filter will result in large measurement errors under slightly high heart rate and slightly high pulse pressure amplitude. Therefore, to effectively use such compensation, the fluid-filled catheter based intra-arterial blood pressure measurement must be characterized in situ during every intra-arterial blood pressure measurement session. The compensating filter must be adjusted to match the measurement system's characteristic. If the measurement system has frequency bandwidth less than $25 \mathrm{~Hz}$, and is either underdamped or overdamped, the compensating filter can be a low pass filter with a corner cutoff frequency slightly higher than the system's natural frequency, and damping that is the inverse of the system's damping - i.e., if the system is underdamped the compensating filter should be overdamped, and vice versa. The purpose of the compensating filter is to make the overall transfer function of the measurement system have a flat frequency response in the frequency band $0-25 \mathrm{~Hz}$.

\section{Acknowledgements}

The Authors thank the Department of Biotechnology (DBT), Government of India, for funding the study. The Authors are grateful to the medical and technical personnel at the Surgical Intensive Care Unit of Christian Medical College, Vellore for enabling the blood pressure recordings. The technical help provided by Ms. Hamsavardhini V, Ms. Kamatham Shiny Simon, Ms. Anushka Kataria (second year medical students), is gratefully acknowledged. 
medRxiv preprint doi: https://doi.org/10.1101/2020.08.29.20184275; this version posted October 25, 2020. The copyright holder for this preprint (which was not certified by peer review) is the author/funder, who has granted medRxiv a license to display the preprint in perpetuity.

All rights reserved. No reuse allowed without permission.

\section{Sources of Funding}

The study was funded by Department of Biotechnology (DBT), Government of India.

\section{Disclosures}

Nil.

\section{References}

[1] Scott J. Denardo, Ramavathi Nandyala, Gregory L. Freeman, Gary L. Pierce, Wilmer W. Nichols, Pulse Wave Analysis of the Aortic Pressure Waveform in Severe Left Ventricular Systolic Dysfunction. Circ Heart Fail, January 2010, pp.149-156. DOI: 10.1161/CIRCHEARTFAILURE.109.862383.

[2] S Devasahayam, Signals and Systems in Biomedical Engineering: Physiological Systems Modeling and Signal Processing, $3^{\text {rd }}$ Edition, Springer 2019. DOI: 10.1007/978-981-13-3531-0.

[3]R.M.Gardner, Direct Blood Pressure Measurement: Dynamic Response Requirement, Anesthesiology, 54:227-236, 1981. DOI: $10.1097 / 00000542-198103000-00010$

[4] Reed M.Gardner, Direct arterial pressure monitoring. Current Anaesthesia \& Critical Care. Volume 1, Issue 4, September 1990, Pages 239-246. DOI: 10.1016/0953-7112(90)90008.

[5] Webster JG. Encyclopedia of medical devices and instrumentation. Hoboken, N.J.: WileyInterscience; 2006.

[6] Hall JE. Guyton and Hall textbook of medical physiology. Elsevier; 2016.

[7] Jörn Grensemann, Cardiac Output Monitoring by Pulse Contour Analysis, the Technical Basics of Less-invasive Techniques. Frontiers in Medicine, March 2018, Volume 5,Article 64. DOI: 10.3389/fmed.2018.00064.

[8] Mathieu Jozwiak, Xavier Monnet, and Jean-Louis Teboul, Pressure Waveform Analysis. Anesthesia and Analgesia, June 2018, Volume 126, Number 6. DOI: 10.1213/ ANE. 0000000000002527. 
medRxiv preprint doi: https://doi.org/10.1101/2020.08.29.20184275; this version posted October 25, 2020. The copyright holder for this preprint (which was not certified by peer review) is the author/funder, who has granted medRxiv a license to display the preprint in perpetuity.

All rights reserved. No reuse allowed without permission.

[9] Bouchra Lami, Denis Chemla, Christian Richard and Jean-Louis Teboul, Clinical review: Interpretation of arterial pressure wave in shock states. Critical Care 2005, 9:601-606. DOI $10.1186 / \operatorname{cc} 3891$.

[10] C. Slagt, I. Malagon and A. B. J. Groeneveld, Systematic review of uncalibrated arterial pressure waveform analysis to determine cardiac output and stroke volume variation. British Journal of Anaesthesia 112 (4): 626-37 (2014). DOI: 10.1093/bja/aet429.

[11] Mahesh Nirmalan, Paul M Dark,, Broader applications of arterial pressure wave form analysis. Continuing Education in Anaesthesia, Critical Care \& Pain, Volume 14 Number 6 2014. DOI: 10.1093/bjaceaccp/mkt078.

[12] Stefano Romagnoli, Zaccaria Ricci, Diego Quattrone, Lorenzo Tofani, Omar Tujjar, Gianluca Villa, Salvatore M Romano and A Raffaele De Gaudio, Accuracy of invasive arterial pressure monitoring in cardiovascular patients: an observational study. Critical Care 2014, 18:644. doi:10.1186/s13054-0140644-4.

[13] Chambers, D., Huang, C., \& Matthews, G. (2019). Arterial Pressure Waveforms. In Basic Physiology for Anaesthetists (pp. 155-157). Cambridge: Cambridge University Press. doi:10.1017/9781108565011.038. 
medRxiv preprint doi: https://doi.org/10.1101/2020.08.29.20184275; this version posted October 25, 2020. The copyright holder for this preprint (which was not certified by peer review) is the author/funder, who has granted medRxiv a license to display the preprint in perpetuity. All rights reserved. No reuse allowed without permission.

\section{Tables}

Table 1. Errors for various measurement systems and compensating filters

\begin{tabular}{|c|c|c|c|c|c|c|c|}
\hline & \multicolumn{7}{|c|}{ Error in mmHg. Mean error in top-left of cell, Systolic error in bottom-right of cell } \\
\hline & \multicolumn{4}{|c|}{ Slow waveform } & \multicolumn{3}{|c|}{ Fast waveform } \\
\hline & No filter & & $\begin{array}{l}\text { filter } 1 \\
8 \mathrm{~Hz}, 1.5\end{array}$ & $\begin{array}{l}\text { Filter } 2 \\
30 \mathrm{~Hz}, 1.5\end{array}$ & No filter & $\begin{array}{l}\text { Filter } 1 \\
18 \mathrm{~Hz}, 1.5\end{array}$ & $\begin{array}{l}\text { Filter } 2 \\
30 \mathrm{~Hz}, 1.5\end{array}$ \\
\hline \begin{tabular}{|l} 
Measurement \\
System 1 \\
$f_{\text {natural }}=12 \mathrm{~Hz}$ \\
$Z_{\text {damping }}=0.25$
\end{tabular} & 0.73 & & 0.1 & 0.4 & 18.4 & 1.6 & 2.3 \\
\hline $\begin{array}{l}\text { Measurement } \\
\text { System 2 } \\
f_{\text {natural }}=20 \mathrm{~Hz} \\
Z_{\text {damping }}=0.25\end{array}$ & 0.28 & & -0.7 & -0.2 & 1.4 & -4.1 & 0.8 \\
\hline
\end{tabular}


medRxiv preprint doi: https://doi.org/10.1101/2020.08.29.20184275; this version posted October 25, 2020. The copyright holder for this preprint (which was not certified by peer review) is the author/funder, who has granted medRxiv a license to display the preprint in perpetuity.

All rights reserved. No reuse allowed without permission.

\section{Mathematical Appendix}

\section{I: Blood pressure waveform}

The arterial pressure waveform can be simulated compactly by Fourier synthesis, with at least 20 sinusoids with magnitude, $M_{k}$, and phase, $\phi_{k}: P(t)=P_{d}+\left(P_{s}-P_{d}\right) \sum_{k=0}^{20} M_{k} \cos \left(2 \pi k f_{o} t-\phi_{k}\right)$. $f_{\mathrm{o}}=($ heart rate in beats $/ \mathrm{min}) / 60, P_{s}=$ systolic pressure and $P_{d}=$ diastolic pressure

\begin{tabular}{|l|l|l|l|l|l|l|l|l|l|l|l|l|l|l|l|l|l|l|l|l|l|}
\hline$k$ & 0 & 1 & 2 & 3 & 4 & 5 & 6 & 7 & 8 & 9 & 10 & 11 & 12 & 13 & 14 & 15 & 16 & 17 & 18 & 19 & 20 \\
\hline$M_{k}$ & 0.4486 & 0.365 & 0.1825 & 0.1194 & 0.0567 & 0.0294 & 0.0448 & 0.0277 & 0.0117 & 0.0208 & 0.0172 & 0.0064 & 0.0112 & 0.0124 & 0.0044 & 0.0066 & 0.0074 & 0.0054 & 0.0023 & 0.0045 & 0.0030 \\
\hline$\phi_{k}$ & 0.0 & 3.169 & 5.034 & 0.709 & 2.8 & 3.843 & 5.445 & 1.378 & 2.712 & 4.061 & 6.142 & 1.6 & 2.7 & 4.831 & 0.453 & 1.307 & 3.522 & 5.61 & 5.73 & 1.197 & 4.0 \\
\hline
\end{tabular}

\section{II: Calculation of catheter system characteristics from physical properties}

The effective resistance, $R$, capacitance, $C$, and inductance (inertance), $L$, of the system and the natural frequency, $f_{n}$, and damping coefficient, $\zeta$, are calculated using the equations given below. The total capacitance depends on the compliance of the diaphragm, the compliance of the catheter, and the isothermal compression of the air bubbles trapped in the fluid.

$R=\frac{8 \eta l}{\pi r^{4}} L=\frac{\rho l}{\pi r^{2}} C=\frac{1}{F_{d}}+C_{c}+\frac{\Delta V}{\Delta P} \vee_{\text {bubble }}, C_{C}=\frac{2 \pi r^{3} l}{E_{C} h}, f_{n}=\frac{1}{2 \pi \sqrt{L C}}, \zeta=\frac{R}{2} \sqrt{\frac{C}{L}}$

\section{III: Calculation of catheter system characterisitics from Fast-flush test}

Measuring the time, $t_{n}$, and amplitude swing, $y_{n}$, (deviation from the mean arterial pressure) of the $n^{\text {th }}$ maximum, the natural frequency and damping coefficient can be calculated as follows:

$$
\zeta=\frac{\alpha}{1+\alpha^{2}}, f_{n}=\frac{1}{t_{n+1}-t_{n}} \cdot \frac{1}{\sqrt{1-\zeta^{2}}}, \quad \text { where }, \quad \alpha=\log _{e}\left(\frac{y_{n}}{y_{n+1}}\right)
$$

\section{IV: Definition of waveform errors}

(a) Mean error: $e_{\text {mean }}=\frac{1}{T} \int_{0}^{T}\left[P_{m}(t)-P_{i}(t-\tau)\right] d t \quad T=$ cardiac cycle duration, $\tau=$ time shift to compensate for phase lag of the measurement system (i.e., shift at which the mean error is minimum)

(b) Systolic error, $e_{s}=\max \left[P_{m}(t)\right]-\max \left[P_{i}(t)\right]$

(c) Diastolic error, $e_{d}=\min \left[P_{m}(t)\right]-\min \left[P_{i}(t)\right]$

(subscript ' $\mathrm{m}$ ' is for the measured waveform and subscript ' $\mathrm{i}$ ' for the true waveform) 